\title{
Research on the Profitability of Rural Banks in Indonesia: A Comparative Study
}

\author{
Roberto Akyuwen* \\ Master of Management, Universitas Pancasakti Tegal, Indonesia \\ *Corresponding author. Email: akyuwenroberto@gmail.com
}

\begin{abstract}
BPRs' size, in terms of asset and capital, is substantially smaller than the commercial banks. However, they are playing a significant role in supporting micro and small enterprises. The total number of BPRs today is more than 1,500 units and spread all over Indonesia. One of the most important performance indicators of BPR is profitability. This research is aimed at comparing previous researches on factors affecting the profitability of BPRs. In total, 23 types of research from 2014 to 2021 are gathered and compared. The comparison will embrace the use of analysis tools, dependent and independent variables, and relationships pattern among those variables. The result shows that a multiple linear regression was the most frequent tool of analysis used by researchers in analyzing factors affecting BPR's profitability. The other tool of analysis with a relatively limited utilization was a panel data regression and path analysis. The return on assets (ROA) was identified as the most intensive dependent variable used in representing BPR's profitability. Meanwhile, the capital adequacy ratio (CAR), loan to deposit ratio (LDR), nonperforming loan (NPL), and operating income to operational expenses ratio (BOPO) were the most frequent independent variables used by various studies.
\end{abstract}

Keywords: BOPO, BPR, CAR, Comparison, LDR, NPL, Profitability, ROA.

\section{INTRODUCTION}

Bank Perkreditan Rakyat (BPR) is a typical rural bank in Indonesia. This type of bank is basically dedicated to supporting economic development at the local level. Although most of BPRs are relatively smaller if compared to commercial banks, however, they are playing very important roles in financing micro and small enterprises. Currently, there are more than 1,500 active BPRs spread all over Indonesia. According to the regulation, BPRs' operation, especially in providing loans, is restricted within province and neighbors' regencies or municipalities. In addition, different from the commercial banks, BPRs also have many limitedness in undertaking their businesses.

Various restrictions of BPRs are mainly related to their lower capital and asset ownership if compared to the commercial banks, although currently there are several big scales of BPRs in the industry. Furthermore, the total assets and core capital of the biggest BPRs are higher than several Regional Development Banks (BPDs). According to the Indonesia Financial Services Authority
(OJK) data, in June 2021, there were 1,666 active BPRs spread all over Indonesia. With these huge numbers and coverage including in suburban and remote areas, in many cases, BPRs have become a main financial provider for middle to low-income people and micro, small and medium enterprises (MSMEs). Focusing on these market segments has made BPRs become strategic in alleviating local economic development problems such as poverty, unemployment, and disparity.

However, BPRs' management often is not able to contribute optimally in supporting economic development at the local level. One of the main causes of this phenomenon is the increasing competition with other financial institutions, especially commercial banks and fintech lending or peer-to-peer lending. BPRs' market share is under pressure continuously, because those financial institutions are also targeting a similar market segment, in particular micro and small enterprises. As a consequence, BPRs' management is often found difficulties in improving their financial performance including profitability. Some of BPRs 
are able to adapt by adopting various recent approaches such as implementing digital products and services, but most of BPRs are not begin this effort yet. As a regulator, OJK has begun to adjust various regulations in order to provide flexibility for BPRs in undertaking their businesses and improving their competitiveness. The arrival of the Corona Virus Diseases 2019 (Covid-19) pandemic in Indonesia has increased the challenges faced by BPRs' management.

Those phenomena have encouraged many researchers to study various factors affecting the profitability of BPRs. Studies have been conducted in various regencies and municipalities in Indonesia which have different characteristics. For example, [1] has observed 4 BPRs in Padang City, [2] have analyzed 18 BPRs in Denpasar City, and [3] has studied 6 BPRs in Banyumas Regency. Besides, there were also several studies on BPRs at the provincial level. Among others, [4] have observed 16 BPRs in Riau Province, [5] analyzed 12 BPR in West Kalimantan Province, who has studied 48 BPRs in East Java Province. [6]

This research is aimed at comparing various researches on factors affecting the profitability of BPRs. All researches under comparison are conducted between the years 2014 and 2021. Twenty-three previous studies were compared to each other in order to understand the similarities and differences as well. The various aspects compared mainly include the tools of analysis, type of dependent and independent variables, and researches' findings. The comparison will reveal the consistency and also a contradiction of the previous researches. [7] for instance, have found that the Capital Adequacy Ratio (CAR) has a significant and positive influence on the Return on Asset (ROA) as a representative of BPR's profitability. This finding is similar to [8] but different to $[9,10]$. These two researchers concluded that CAR has no impact on BPR's ROA.

\section{LITERATURE REVIEW}

BPR is a bank that conducting the conventional business without involve in the clearing mechanism (OJK Regulation No. 62/POJK.03/2020 on Bank Perkreditan Rakyat). In addition, in article 4 OJK Regulation No. 12/ POJK.03/2016 on BPR's Business and Networks based on Core Capital, it is mentioned that BPR's business activities are include collecting funds, distributing funds, placement of funds, money changer, and other supporting activities. BPR's management is expected to manage these business activities optimally to make it able to compete and sustain in the market. a bank's performance is closely related to its functions and roles. [11] A successful bank will be able to create profit as an achievement of the management. The performance of a bank is highly dependent on the capability of the management.

Many kinds of literature have revealed that BPR has a vital role in supporting people's economy, especially the MSMEs' development in Indonesia. To optimize this role, a BPR must have a better performance, and one the most important performance indicators is creating profit. [12] has emphasized that profitability is one of the key successes of BPR's operation. Profitability means a bank's ability to get profit through the utilization of all capabilities and resources such as cash turnover, credit risk management, third party funds, and liquidity. Furthermore, to maximize profitability, a bank's management must understand factors that have substantial impacts. According to Bank Indonesia, the most important indicator for profitability is ROA. [13]

ROA has been used as an indicator in most of researches on factors affecting the profitability of BPR. ROA formula is as follow [9]

$$
\text { ROA }=\frac{\text { Gross } \text { Profit }}{\text { Total Asset }} \times 100 \%
$$

Meanwhile, the internal factors that have been used as independent variables by researchers were varied. However, the most intensive indicators were CAR, LDR, BOPO, and NPL. The formula for each indicator is as follows [3,6,9,14-17]

$$
\begin{aligned}
& C A R=\frac{\text { Bank's Capital }_{\text {Risk Weighted Assets }}}{\text { Ret }} \times 100 \% \\
& L D R=\frac{\text { Total Credit }}{\text { Third Party Funds }} \times 100 \% \\
& B O P O=\frac{\text { operational Cost }}{\text { Operational Income }} \times 100 \% \\
& N P L=\frac{\text { Bad Credit }}{\text { Total Credit }} \times 100 \%
\end{aligned}
$$

\section{RESEARCH METHOD}

Based on the objective, this research is classified into a qualitative comparative study. A comparative 
study is basically undertaken to identify the similarities and differences among objects, procedures, ideas, and others. A comparative study can also direct toward different perspectives of people or group of people on a specific event or idea. Meanwhile, from the data collection procedure, this research is can be categorized as a literature study because the main source of data is articles gathered from various academic papers, in particular journals and theses.

Compared objects in this research were 23 previous studies about factors affecting BPR's profitability in Indonesia. These studies were undertaken in various regions between 2014 to 2021 . The comparison is mainly conducted on the tools of analysis, type of dependent and independent variables, and results or findings.

After conducting comparisons, the most intensive tools of analysis will be identified, including its consistency on the researches' findings. Moreover, the most frequent type of dependent variables used by researchers to represent BPR's profitability can also be identified. Besides, this research will identify type of independent variables which are often hypothesized in the previous studies to represent factors affecting the profitability of BPR. Finally, finding among different researches can also be compared.

\section{DISCUSSION}

Many researchers have made serious efforts for years to identify factors affecting BPR's profitability in Indonesia. However, it is found that there were only two type of analysis tools that have been used intensively by them i.e., multiple linear regression and panel data regression (Table 1). The other tool of analysis was a path analysis used by Wardani [17] Researchers who were using a multiple linear regression in their studies were Afriyeni [11]Afriyeni and Fernos [1]Agustini and Budiasih [7], Anggraeni [12], Astohar and Sumiyanti [13]Aziri et al [18], Cahyono [9] Gustika [14] Hanifa et al [19], Pandoyo [10] Pertiwi and Suardhika [20] Putri et al [2] Sari [16] Simanjuntak [21], Wardhani and Ismunawan [17] and Yuliati et al [22] Meanwhile, studies undertaken using a panel data regression were Azizah and Masdjojo[23] Maryadi and Basuki [15], Sahfitri [3] Sakat [5] and Sofyan [6]

Multiple linear regression is principally easier to apply if compared to panel data regression in the context of data inputting, estimation processing, and also interpretation. These factors are probably become one of the main reasons for most of the researchers to utilize it. Although, the use of time series data in a multiple linear regression, in particular for more than one BPR as the research object, requires a careful confirmation because the data used was not a direct data from each BPR, but an average data. Whereas in a statistical calculation to provide a coefficient value for each independent variable, there is also data averaging process. Besides, the build multiple linear regression model must fulfill all classic assumption with no exception, including normality, autocorrelation, heteroscedasticity, and multicollinearity tests, before being interpreted. Normality test can be conducted using a histogram test or Jarque-Bera, while autocorrelation test is undertaken by using Breusch-Godfrey Serial Correlation LM Test. In addition, heteroscedasticity test is conducted using Glejser test and the Varian Inflation Factors (VIF) can be used for multicollinearity test. General form of the multiple linear regression model used by the researchers observed in this research is as follow:

$y=$ dependent variable; $x=$ independent variables; $\varepsilon=$ error term, $i=1,2,3, \ldots, n$, and $t=$ time

$$
y_{i t}=\alpha_{0}+\alpha_{i} x_{i t}+\cdots+\alpha_{n} x_{n t}+\varepsilon_{i t}
$$

Different to a multiple linear regression, a panel data regression must follow the financial ratio data inputting process. These data are relevant to the BPR's profitability and the process are more complicated because it requires a combination between time series and cross-section data. In short, several BPRs are observed and analyzed in several periods at once. A panel data regression can be a one-way or two-way model. A one-way model only considers BPR's effect, while two-way model also considers the time effect. The general form of oneway and two-way panel data regression model is as follows:

$$
\begin{aligned}
& y_{i t}=\alpha+\alpha_{i}+X_{i t}^{\prime} \beta+\varepsilon_{i t} \\
& y_{i t}=\alpha+\alpha_{i}+\delta_{t}+X_{i t}^{\prime} \beta+\varepsilon_{i t}
\end{aligned}
$$

In addition, an estimation of panel data regression model has three alternative approaches i.e., common effect model (CE) or pooled least square (PLS), fixed effect model (FE), and random effect model (RE). To determine a suitable estimation model, various tests must be undertaken such as Chow test to choose between CE or FE, Hausman test to choose between FE or RE, and Lagrange Multiplier test to choose between RE and CE. 
Table 1. Researchers, Research Object, and Analysis Tool used in the Researches on Factors Affecting BPR's Profitability in Indonesia

\begin{tabular}{|c|c|c|c|}
\hline No. & $\begin{array}{c}\text { Researchers } \\
\text { and Year }\end{array}$ & $\begin{array}{c}\text { Research } \\
\text { Object }\end{array}$ & Analysis Tool \\
\hline 1. & $\begin{array}{l}\text { Afriyeni } \\
\text { (2017) }\end{array}$ & $\begin{array}{l}4 \text { BPRs in } \\
\text { Padang City }\end{array}$ & $\begin{array}{l}\text { Multiple Linear } \\
\text { Regression }\end{array}$ \\
\hline 2. & $\begin{array}{l}\text { Afriyeni and } \\
\text { Fernos } \\
(2018)\end{array}$ & $\begin{array}{l}85 \text { BPRs in } \\
\text { West } \\
\text { Sumatera } \\
\text { Province }\end{array}$ & $\begin{array}{l}\text { Multiple Linear } \\
\text { Regression }\end{array}$ \\
\hline 3. & $\begin{array}{l}\text { Agustini and } \\
\text { Budiasih } \\
\text { (2014) }\end{array}$ & $\begin{array}{l}31 \text { BPRs in } \\
\text { Badung } \\
\text { Regency }\end{array}$ & $\begin{array}{l}\text { Multiple Linear } \\
\text { Regression }\end{array}$ \\
\hline 4. & $\begin{array}{l}\text { Anggreani } \\
(2021)\end{array}$ & $\begin{array}{l}8 \text { BPRs in } \\
\text { Tegal } \\
\text { Regency }\end{array}$ & $\begin{array}{l}\text { Multiple Linear } \\
\text { Regression }\end{array}$ \\
\hline 5. & $\begin{array}{l}\text { Astohar and } \\
\text { Sumiyanti } \\
(2018)\end{array}$ & $\begin{array}{l}8 \text { Big BPRs in } \\
\text { Indonesia }\end{array}$ & $\begin{array}{l}\text { Multiple Linear } \\
\text { Regression }\end{array}$ \\
\hline 6. & $\begin{array}{l}\text { Aziri et al } \\
(2018)\end{array}$ & $\begin{array}{l}18 \text { BPRs in } \\
\text { Pekanbaru } \\
\text { City }\end{array}$ & $\begin{array}{l}\text { Multiple Linear } \\
\text { Regression }\end{array}$ \\
\hline 7. & $\begin{array}{l}\text { Azizah and } \\
\text { Masdjojo } \\
(2018)\end{array}$ & $\begin{array}{l}70 \text { BPRs in } \\
\text { West } \\
\text { Sumatera } \\
\text { Province }\end{array}$ & $\begin{array}{l}\text { Panel Data } \\
\text { Regression }\end{array}$ \\
\hline 8. & $\begin{array}{l}\text { Azwan and } \\
\text { Hasan (2016) }\end{array}$ & $\begin{array}{l}16 \text { BPRs in } \\
\text { Riau } \\
\text { Province }\end{array}$ & $\begin{array}{l}\text { Multiple Linear } \\
\text { Regression }\end{array}$ \\
\hline 9. & $\begin{array}{l}\text { Cahyono } \\
\text { (2018) }\end{array}$ & $\begin{array}{l}1 \text { BPR in } \\
\text { Tulungagung } \\
\text { Regency }\end{array}$ & $\begin{array}{l}\text { Multiple Linear } \\
\text { Regression }\end{array}$ \\
\hline 10. & $\begin{array}{l}\text { Gustika } \\
\text { (2015) }\end{array}$ & $\begin{array}{l}\text { 1 BPRs in } \\
\text { Tanah } \\
\text { Bumbu } \\
\text { Regency }\end{array}$ & $\begin{array}{l}\text { Multiple Linear } \\
\text { Regression }\end{array}$ \\
\hline 11. & $\begin{array}{l}\text { Hanifa et al } \\
\text { (2019) }\end{array}$ & $\begin{array}{l}10 \text { BPRs in } \\
\text { Palembang } \\
\text { City }\end{array}$ & $\begin{array}{l}\text { Multiple Linear } \\
\text { Regression }\end{array}$ \\
\hline
\end{tabular}

\begin{tabular}{|c|c|c|c|}
\hline 12. & $\begin{array}{l}\text { Maryadi and } \\
\text { Basuki (2014) }\end{array}$ & $\begin{array}{l}54 \text { BPRs in } \\
\text { Jogjakarta } \\
\text { Province }\end{array}$ & $\begin{array}{l}\text { Panel Data } \\
\text { Regression }\end{array}$ \\
\hline 13. & $\begin{array}{l}\text { Pandoyo } \\
\text { (2019) }\end{array}$ & $\begin{array}{l}\text { BPRs in West } \\
\text { Java } \\
\text { Province }\end{array}$ & $\begin{array}{l}\text { Multiple Linear } \\
\text { Regression }\end{array}$ \\
\hline 14. & $\begin{array}{l}\text { Pertiwi and } \\
\text { Suardhika } \\
\text { (2015) }\end{array}$ & $\begin{array}{l}15 \text { BPRs in } \\
\text { Gianyar } \\
\text { Regency }\end{array}$ & $\begin{array}{l}\text { Multiple Linear } \\
\text { Regression }\end{array}$ \\
\hline 15. & $\begin{array}{l}\text { Putri et al } \\
\text { (2018) }\end{array}$ & $\begin{array}{l}18 \text { BPRs in } \\
\text { Denpasar } \\
\text { City }\end{array}$ & $\begin{array}{l}\text { Multiple Linear } \\
\text { Regression }\end{array}$ \\
\hline 16. & $\begin{array}{l}\text { Sahfitri } \\
(2021)\end{array}$ & $\begin{array}{l}6 \text { BPRs in } \\
\text { Banyumas } \\
\text { Regency }\end{array}$ & $\begin{array}{l}\text { Panel Data } \\
\text { Regression }\end{array}$ \\
\hline 17. & Sakat (2021) & $\begin{array}{l}12 \text { BPRs in } \\
\text { West } \\
\text { Kalimantan } \\
\text { Province }\end{array}$ & $\begin{array}{l}\text { Panel Data } \\
\text { Regression }\end{array}$ \\
\hline 18. & Sari (2019) & $\begin{array}{l}8 \text { BPRs in } \\
\text { Magelang } \\
\text { Regency }\end{array}$ & $\begin{array}{l}\text { Multiple Linear } \\
\text { Regression }\end{array}$ \\
\hline 19. & $\begin{array}{l}\text { Simanjuntak } \\
\text { (2019) }\end{array}$ & $\begin{array}{l}26 \text { BPRs in } \\
\text { Batam City }\end{array}$ & $\begin{array}{l}\text { Multiple Linear } \\
\text { Regression }\end{array}$ \\
\hline 20. & $\begin{array}{l}\text { Sofyan } \\
\text { (2019) }\end{array}$ & $\begin{array}{l}48 \text { BPRs in } \\
\text { East Java } \\
\text { Province }\end{array}$ & $\begin{array}{l}\text { Panel Data } \\
\text { Regression }\end{array}$ \\
\hline 21. & $\begin{array}{l}\text { Wardani et } \\
\text { al (2021) }\end{array}$ & $\begin{array}{l}39 \text { BPRs in } \\
\text { Bali Province }\end{array}$ & Path Analysis \\
\hline 22. & $\begin{array}{l}\text { Wardhani } \\
\text { and } \\
\text { Ismunawan } \\
(2021)\end{array}$ & $\begin{array}{l}12 \text { BPRs in } \\
\text { Sukoharjo } \\
\text { Regency }\end{array}$ & $\begin{array}{l}\text { Multiple Linear } \\
\text { Regression }\end{array}$ \\
\hline 23. & $\begin{array}{l}\text { Yuliati et al } \\
\text { (2021) }\end{array}$ & $\begin{array}{l}29 \text { BPRs in } \\
\text { Nusa } \\
\text { Tenggara } \\
\text { Barat } \\
\text { Province }\end{array}$ & $\begin{array}{l}\text { Multiple Linear } \\
\text { Regression }\end{array}$ \\
\hline
\end{tabular}

From the region coverage, most of researches were conducted at the regency and municipal levels with more than 1 observed BPR. In the three latest researches, for instance, [12] has studies 8 BPRs in 
Tegal Regency, [3] has analyzed 6 BPRs in Banyumas Regency, [17] have observed 12 BPRs in Sukoharjo Regency. Next, there were several researchers who have studied factors affecting BPRs' profitability at the provincial level. For example, [1] have studied 85 BPRs in West Sumatera Province, [15] have observed all BPRs in Jogjakarta Province, [8] have analyzed 39 BPRs in Bali Province, and [22] have studied 12 BPRs in West Nusa Tenggara Province. Meanwhile, [13] have analyzed 8 BPRs at national level and [14] has only observed 1 BPR in Tanah Bumbu Regency.

In the context of dependent variable, it was found that almost all researchers have used ROA as the only dependent variable to represent the profitability, although from the conceptual perspective, the profitability can be represented also by the Return on Equity (ROE). The researchers who have utilized ROA as a dependent variable were include $[1,2,4,6-13,15,17-20,22,23]$ However, this study also found that there were researchers who have used more than one dependent variable to represent BPR's profitability. [14] for example, has used ROA, ROE, and Net Profit Margin (NPM) to represent BPRs' profitability in Simpang Empat District, Tanah Bumbu Regency, South Kalimantan Province. Besides, [21] has utilized ROA and BOPO as dependent variable in their study about factors affecting profitability in 26 BPRs operated in Batam City.

Table 2. Researchers and Independent and Dependent Variables used in the Researches on Factor Affecting BPR's Profitability in Indonesia

\begin{tabular}{|c|l|l|l|}
\hline No. & $\begin{array}{l}\text { Researchers } \\
\text { and Year }\end{array}$ & $\begin{array}{c}\text { Dependent } \\
\text { Variables }\end{array}$ & $\begin{array}{l}\text { Independent } \\
\text { Variables }\end{array}$ \\
\hline 1. & $\begin{array}{l}\text { Afriyeni } \\
\text { (2017) }\end{array}$ & ROA & $\begin{array}{l}\text { LDR and Loan } \\
\text { to Asset Ratio } \\
\text { (LAR) }\end{array}$ \\
\hline 2. & $\begin{array}{l}\text { Afriyeni and } \\
\text { Fernos } \\
\text { (2018) }\end{array}$ & ROA & $\begin{array}{l}\text { CAR, LDR, } \\
\text { BOPO, and } \\
\text { NPL }\end{array}$ \\
\hline 3. & $\begin{array}{l}\text { Agustini and } \\
\text { Budiasih } \\
\text { (2014) }\end{array}$ & ROA & $\begin{array}{l}\text { CAR, LDR, and } \\
\text { NPL }\end{array}$ \\
\hline 4. & $\begin{array}{l}\text { Anggreani } \\
\text { (2021) }\end{array}$ & ROA & $\begin{array}{l}\text { Cash Turnover, } \\
\text { NPL, DPK, and } \\
\text { LDR }\end{array}$ \\
\hline 5. & $\begin{array}{l}\text { Astohar and } \\
\text { Sumiyanti } \\
\text { (2018) }\end{array}$ & ROA & $\begin{array}{l}\text { CAR, NPL, LDR, } \\
\text { BOPO, and } \\
\text { NIM }\end{array}$ \\
\hline
\end{tabular}

\begin{tabular}{|c|c|c|c|}
\hline 6. & $\begin{array}{l}\text { Aziri et al } \\
\text { (2018) }\end{array}$ & $\mathrm{ROA}$ & $\begin{array}{l}\text { CAR, LDR, NPL, } \\
\text { and BOPO }\end{array}$ \\
\hline 7. & $\begin{array}{l}\text { Azizah and } \\
\text { Masdjojo } \\
\text { (2018) }\end{array}$ & $\mathrm{ROA}$ & $\begin{array}{l}\text { NPL, LDR, } \\
\text { BOPO, and } \\
\text { CAR }\end{array}$ \\
\hline 8. & $\begin{array}{l}\text { Azwan and } \\
\text { Hasan (2016) }\end{array}$ & $\mathrm{ROA}$ & $\begin{array}{l}\text { CAR, LDR, NPL, } \\
\text { and BOPO }\end{array}$ \\
\hline 9. & $\begin{array}{l}\text { Cahyono } \\
\text { (2018) }\end{array}$ & $\mathrm{ROA}$ & $\begin{array}{l}\text { CAR, LDR, and } \\
\text { BOPO }\end{array}$ \\
\hline 10. & $\begin{array}{l}\text { Gustika } \\
\text { (2015) }\end{array}$ & $\begin{array}{l}\text { ROA, ROE, } \\
\text { and NPM }\end{array}$ & $\mathrm{BOPO}$ \\
\hline 11. & $\begin{array}{l}\text { Hanifa et al } \\
\text { (2019) }\end{array}$ & $\mathrm{ROA}$ & $\begin{array}{l}\mathrm{CAR}, \mathrm{NPL} \text {, } \\
\text { BOPO, and } \\
\text { LDR }\end{array}$ \\
\hline 12. & $\begin{array}{l}\text { Maryadi and } \\
\text { Basuki (2014) }\end{array}$ & $\mathrm{ROA}$ & $\begin{array}{l}\text { LDR, NPL, CAR, } \\
\text { and BOPO }\end{array}$ \\
\hline 13. & $\begin{array}{l}\text { Pandoyo } \\
\text { (2019) }\end{array}$ & $\mathrm{ROA}$ & $\begin{array}{l}\text { CAR, LDR, } \\
\text { BOPO, and } \\
\text { NPL }\end{array}$ \\
\hline 14. & $\begin{array}{l}\text { Pertiwi and } \\
\text { Suardhika } \\
\text { (2015) }\end{array}$ & $\mathrm{ROA}$ & $\begin{array}{l}\text { Credit } \\
\text { Turnover, Cash } \\
\text { Turnover, and } \\
\text { Total Debtor }\end{array}$ \\
\hline 15. & $\begin{array}{l}\text { Putri et al } \\
\text { (2018) }\end{array}$ & $\mathrm{ROA}$ & $\begin{array}{l}\text { NPL, CAR, and } \\
\text { BOPO }\end{array}$ \\
\hline 16. & $\begin{array}{l}\text { Sahfitri } \\
\text { (2021) }\end{array}$ & $\mathrm{ROA}$ & $\begin{array}{l}\mathrm{BOPO}, \mathrm{NPL} \text {, } \\
\text { and LDR }\end{array}$ \\
\hline 17. & Sakat (2021) & $\mathrm{ROA}$ & $\begin{array}{l}\text { NPL, LDR, } \\
\text { BOPO, NIM, } \\
\text { and CAR }\end{array}$ \\
\hline 18. & Sari (2019) & $\mathrm{ROA}$ & $\begin{array}{l}\text { CAR, NPL, LDR, } \\
\text { and BOPO }\end{array}$ \\
\hline 19. & $\begin{array}{l}\text { Simanjuntak } \\
\text { (2019) }\end{array}$ & $\begin{array}{l}\text { ROA and } \\
\text { BOPO }\end{array}$ & $\begin{array}{l}\text { Credit } \\
\text { Provision and } \\
\text { NPL }\end{array}$ \\
\hline 20. & $\begin{array}{l}\text { Sofyan } \\
(2019)\end{array}$ & $\mathrm{ROA}$ & $\begin{array}{l}\text { CAR, LDR, } \\
\text { BOPO, and } \\
\text { NPL }\end{array}$ \\
\hline 21. & $\begin{array}{l}\text { Wardani et } \\
\text { al (2021) }\end{array}$ & $\mathrm{ROA}$ & $\begin{array}{l}\text { CAR, LDR, and } \\
\text { NPL }\end{array}$ \\
\hline
\end{tabular}




\begin{tabular}{|c|l|l|l|}
\hline 22. & $\begin{array}{l}\text { Wardhani } \\
\text { and } \\
\text { Ismunawan } \\
(2021)\end{array}$ & ROA & $\begin{array}{l}\text { NPL, BOPO, } \\
\text { LDR, and NIM }\end{array}$ \\
\hline 23. & $\begin{array}{l}\text { Yuliati et al } \\
\text { (2021) }\end{array}$ & ROA & $\begin{array}{l}\text { Credit Risk, } \\
\text { Liquidity Risk, } \\
\text { and Asset Risk }\end{array}$ \\
\hline
\end{tabular}

A compilation presented in Table 2 shows that the types of the independent variable used to describe factors affecting BPR's profitability were vary in the previous researches. However, a careful observation reveals that there were four most intensive independent variables used by researchers. They were CAR, LDR, BOPO, and NPL. In total, there were 21 out of 23 researches who have involved one or more independent variables from those four most intensive independent variables in their studies. Only [20,22] who were not utilized those four independent variables at all. [20] have used credit turnover, cash turnover, and number of debtors as factors affecting the profitability of 15 BPRs in Gianyar Regency, Bali Province. Meanwhile, [22] have accommodated credit risk, liquidity risk, and asset risk as the independent variables that affecting the profitability of 29 BPRs in West Nusa Tenggara Province.

The other independent variables that have been used by researchers with low frequency were the Net Interest Margin (NIM) and Loan to Asset Ratio (LAR). NIM has been used as one of independent variables [5,11,13,17] has utilized Loan at Risk (LAR) and Loan to Deposit Ratio (LDR) to represent independent variables on their study about factors affecting the profitability of 4 BPRs in Padang City, West Sumatera Province.

The most interesting things are about the findings or conclusions of the previous researches because they are not only having the similarities but also contradictive properties. As seen at Table 3, several researchers
$[1,2,7,15,17]$ have found that a capital sufficiency factor as represented by CAR has a significant and positive impact on ROA. This mean that every increase of ROA will encourage the improvement of BPR's profitability. Meanwhile, the other studies have concluded that CAR has a significant but negative influence on BPR's profitability as represented by ROA. Every increase in CAR will be followed by a decrease in BPR's ROA, with a ceteris paribus assumption. In addition, [4,5,9,10,16,19] have found that CAR change has no effect on BPR's ROA.

Similar fact was also found in the impact of LDR and BOPO on BPR's ROA. [7,8,12] were researchers who have concluded that LDR as a representative of BPR's credit distribution has a significant and positive influence on ROA. This mean that the profitability of BPRs will increase if their credit distribution is improved. However, $[6,13,15]$ have found a significant but negative impact of BPR's LDR on ROA. Every increase in LDR, with a ceteris paribus assumption, will decrease BPR's ROA. Meanwhile, many more studies have found no effect of LDR on BPR's ROA.

Different to the capital sufficiency and credit distribution impacts on the BPR's profitability which have been discussed before, almost all researchers have identified a significant and negative impact of efficiency factor on the profitability of BPR consistently. The efficiency factor was represented by BOPO as an independent variable. These researchers were included [1$3,5,6,8-10,13,15,16,23]$. A significant but negative influence means that an increase in BOPO will encourage a decrease in BPR's ROA, with a ceteris paribus assumption. Only [18,19] who have concluded that BOPO have no impact on BPR's ROA.

Table 3. Research Conclusions in the Researches on Factors Affecting BPR's Profitability in Indonesia

\begin{tabular}{|c|l|l|}
\hline No. & \multicolumn{1}{|c|}{$\begin{array}{c}\text { Researchers } \\
\text { and Year }\end{array}$} & \multicolumn{1}{c|}{ Research Conclusions } \\
\hline 1. & Afriyeni (2017) & $\begin{array}{l}\text { - LDR has no influence on ROA. } \\
\text { - LAR has no influence on ROA. } \\
\text { - LDR and LAR has no simultaneous influence on ROA. }\end{array}$ \\
\hline 2. & $\begin{array}{l}\text { Afriyeni and } \\
\text { Fernos (2018) }\end{array}$ & $\begin{array}{l}\text { - CAR has a significant and positive influence on ROA. } \\
\text { - LDR has a significant and positive influence on ROA. }\end{array}$ \\
\hline
\end{tabular}




\begin{tabular}{|c|c|c|}
\hline & & $\begin{array}{l}\text { - BOPO has a significant and negative influence on ROA. } \\
\text { - NPL has a significant and negative influence on ROA. }\end{array}$ \\
\hline 3. & $\begin{array}{l}\text { Agustini and } \\
\text { Budiasih (2014) }\end{array}$ & $\begin{array}{l}\text { - CAR has a significant and positive influence on ROA. } \\
\text { - LDR has a significant and positive influence on ROA. } \\
\text { - NPL has a significant and negative influence on ROA. }\end{array}$ \\
\hline 4. & Anggreani (2021) & $\begin{array}{l}\text { - Cash Turnover has no influence on ROA. } \\
\text { - NPL has a significant and negative influence on ROA. } \\
\text { - TPF has no influence on ROA. } \\
\text { - LDR has a significant and positive influence on ROA. } \\
\text { - Cash Turnover, NPL, TPF, and NPL has a significant influence simultaneously on } \\
\text { ROA. }\end{array}$ \\
\hline 5. & $\begin{array}{l}\text { Astohar and } \\
\text { Sumiyanti (2018) }\end{array}$ & $\begin{array}{l}\text { - CAR has a significant and negative influence on ROA. } \\
\text { - NPL has a significant and negative influence on ROA. } \\
\text { - LDR has a significant and negative influence on ROA. } \\
\text { - BOPO has a significant and negative influence on ROA. } \\
\text { - NIM has a significant and positive influence on ROA. }\end{array}$ \\
\hline 6. & Aziri et al (2018) & $\begin{array}{l}\text { - CAR has a significant and negative influence on ROA. } \\
\text { - LDR has no influence on ROA. } \\
\text { - NPL has a significant and positive influence on ROA. } \\
\text { - BOPO has no influence on ROA. }\end{array}$ \\
\hline 7. & $\begin{array}{l}\text { Azizah and } \\
\text { Masdjojo (2018) }\end{array}$ & $\begin{array}{l}\text { - NPL has a significant and negative influence on ROA. } \\
\text { - LDR has no influence on ROA. } \\
\text { - BOPO has a significant and negative influence on ROA. } \\
\text { - CAR has a significant and negative influence on ROA. }\end{array}$ \\
\hline 8. & $\begin{array}{l}\text { Azwan and Hasan } \\
\text { (2016) }\end{array}$ & $\begin{array}{l}\text { - CAR has no influence on ROA. } \\
\text { - LDR has no influence on ROA. } \\
\text { - NPL has a significant and negative influence on ROA. } \\
\text { - BOPO has no influence as a moderating variable. }\end{array}$ \\
\hline 9. & Cahyono (2018) & $\begin{array}{l}\text { - CAR has no influence on ROA. } \\
\text { - LDR has no influence on ROA. } \\
\text { - BOPO has a significant and negative influence on ROA. }\end{array}$ \\
\hline 10. & Gustika (2015) & $\begin{array}{l}\text { - BOPO has a significant and negative influence on NPM. } \\
\text { - BOPO has no influence on ROA. } \\
\text { - BOPO has no influence on ROE. }\end{array}$ \\
\hline 11. & Hanifa et al (2019) & $\begin{array}{l}\text { - CAR, NPL, BOPO, and LDR has a significant influence simultaneously on ROA. } \\
\text { - CAR has no influence on ROA. } \\
\text { - NPL has a significant and negative influence on ROA. } \\
\text { - BOPO has no influence on ROA. } \\
\text { - LDR has no influence on ROA. }\end{array}$ \\
\hline 12. & $\begin{array}{l}\text { Maryadi dan } \\
\text { Basuki (2014) }\end{array}$ & $\begin{array}{l}\text { - LDR has no influence on ROA. } \\
\text { - NPL has a significant and negative influence on ROA. } \\
\text { - CAR has a significant and positive influence on ROA. }\end{array}$ \\
\hline
\end{tabular}




\begin{tabular}{|c|c|c|}
\hline & & - BOPO has a significant and negative influence on ROA. \\
\hline 13. & Pandoyo (2019) & $\begin{array}{l}\text { - CAR has no influence on ROA. } \\
\text { - LDR has no influence on ROA. } \\
\text { - BOPO has a significant and negative influence on ROA. } \\
\text { - NPL has no influence on ROA. } \\
\text { - CAR, LDR, BOPO, dan NPL has a significant influence simultaneously on ROA. }\end{array}$ \\
\hline 14. & $\begin{array}{l}\text { Pertiwi and } \\
\text { Suardhika (2015) }\end{array}$ & $\begin{array}{l}\text { - Credit Turnover has a significant and positive influence on ROA. } \\
\text { - Cash Turnover has no influence on ROA. } \\
\text { - Total Debtor has a significant and positive influence on ROA. } \\
\text { - Credit Turnover, Cash Turnover, and Total Debtor has a significant influence } \\
\text { simultaneously on ROA. }\end{array}$ \\
\hline 15. & Putri et al (2018) & $\begin{array}{l}\text { - NPL has a significant and negative influence on ROA. } \\
\text { - CAR has a significant and positive influence on ROA. } \\
\text { - BOPO has a significant and negative influence on ROA. }\end{array}$ \\
\hline 16. & Sahfitri (2021) & $\begin{array}{l}\text { - BOPO, NPL, and LDR has a significant influence simultaneously on ROA. } \\
\text { - BOPO has a significant and negative influence on ROA. } \\
\text { - NPL has no influence on ROA. } \\
\text { - LDR has no influence on ROA. }\end{array}$ \\
\hline 17. & Sakat (2021) & $\begin{array}{l}\text { - NPL has a significant and negative influence on ROA. } \\
\text { - LDR has no influence on ROA. } \\
\text { - BOPO has a significant and negative influence on ROA. } \\
\text { - NIM has a significant and positive influence on ROA. } \\
\text { - CAR has no influence on ROA. } \\
\text { - NPL, LDR, BOPO, NIM, and CAR has a significant influence simultaneously }(97,21 \\
\text { percent) on ROA. }\end{array}$ \\
\hline 18. & Sari (2019) & $\begin{array}{l}\text { - CAR has no influence on ROA. } \\
\text { - NPL has a significant and positive influence on ROA. } \\
\text { - LDR has no influence on ROA. } \\
\text { - BOPO has a significant and negative influence on ROA. } \\
\text { - CAR, NPL, LDR, and BOPO has a significant influence simultaneously on ROA. }\end{array}$ \\
\hline 19. & Simanjuntak (2019) & $\begin{array}{l}\text { - Credit Provision has a significant and negative influence on ROA. } \\
\text { - NPL has a significant and positive influence on ROA. } \\
\text { - Credit Provision and NPL has a significant influence simultaneously on ROA. }\end{array}$ \\
\hline 20. & Sofyan (2019) & $\begin{array}{l}\text { - CAR, LDR, BOPO, and NPL has a significant influence simultaneously on ROA. } \\
\text { - CAR has a significant and negative influence on ROA. } \\
\text { - LDR has a significant and negative influence on ROA. } \\
\text { - BOPO has a significant and negative influence on ROA. } \\
\text { - NPL has no influence on ROA. }\end{array}$ \\
\hline 21. & $\begin{array}{l}\text { Wardani et al } \\
\text { (2021) }\end{array}$ & $\begin{array}{l}\text { - CAR has a significant and positive influence on ROA. } \\
\text { - LDR has a significant and positive influence on ROA. } \\
\text { - NPL has a significant and negative influence on ROA. } \\
\text { - CAR has a significant and positive influence on NPL. }\end{array}$ \\
\hline
\end{tabular}




\begin{tabular}{|c|c|c|}
\hline & & $\begin{array}{l}\text { - LDR has no influence on NPL. } \\
\text { - NPL has no significant influence in moderating CAR influence on ROA. } \\
\text { - NPL has no significant influence in moderating LDR influence on ROA. }\end{array}$ \\
\hline 22. & $\begin{array}{l}\text { Wardhani and } \\
\text { Ismunawan (2021) }\end{array}$ & $\begin{array}{l}\text { - NPL has no influence on ROA. } \\
\text { - BOPO has a significant and negative influence on ROA. } \\
\text { - LDR has no influence on ROA. } \\
\text { - NIM has no influence on ROA. } \\
\text { - NPL, BOPO, LDR, and NIM has a significant influence simultaneously on ROA. }\end{array}$ \\
\hline 23. & Yuliati et al (2021) & $\begin{array}{l}\text { - Credit Risk has no influence on ROA. } \\
\text { - Liquidity Risk has a significant and negative influence on ROA. } \\
\text { - Asset Risk has a significant and positive influence on ROA. }\end{array}$ \\
\hline
\end{tabular}

\section{CONCLUSION}

Based on results and discussion, there are several following conclusions.

1. Majority of studies on factors affecting the profitability of BPRs were conducted at the regency and municipal levels. Each of these studies have observed more than $1 \mathrm{BPR}$. Meanwhile, the other studies were observed BPRs' profitability at the province and national levels.

2. Researchers have utilized 3 tools of analysis i.e., multiple linear regression, panel data regression, and path analysis in identifying factors affecting the profitability of BPRs. Among them, the multiple linear regression was the most intensive analysis tool followed by panel data regression and path analysis.

3. Most of researchers have used ROA as a dependent variable to represent BPRs' profitability in their studies. The other dependent variables with a minimum utilization include ROE, NPM, and BOPO.

4. All researches have only utilized internal factors as the independent variables. The four most intensive independent variables used by researchers were the financial ratios such as LDR, CAR, BOPO, and NPL. Whereas the other type of independent variables with the lower intensity were LAR, Cash Turnover, NIM, Credit Turnover, Number of Debtors, Credit Disbursement, Credit Risk, Liquidity Risk, and Asset Risk.

Factually, BPRs are playing important roles in supporting economic development at local level. For this reason, the forthcoming researchers are suggesting to include the external factors which have relevant impacts on the profitability of BPR. They are including, among others, local economic growth or per capita income and inflation. These factors are conceptually and practically influencing BPR's operational performance, including the profitability.

\section{REFERENCES}

[1] Afriyeni A, Fernos J. ANALISIS FAKTOR-FAKTOR Penentu Kinerja Profitabilitas Bank Perkreditan Rakyat (Bpr) Konvensional Di Sumatera BARAT. Jurnal Benefita 2018;3:325. https://doi.org/10.22216/jbe.v3i3.3623.

[2] Kadek N, Putri AP, Wiagustini LP, Abundanti NN. Pengaruh Npl, Car Dan Bopo Terhadap Profitabilitas Pada Bpr Di Kota Denpasar. Jurnal Manajemen Unud 2018;7:6212-38.

https://doi.org/10.24843/EJMUNUD.2018. v7.i11.p15.

[3] Sahfitri R. Faktor-Faktor Yang Mempengaruhi Profitabilitas Bank Perkreditan Rakyat (BPR) Di Kabupaten Banyumas. 2021.

[4] Azwan, Elvira, Amir H. Analisis FaktorFaktor Yang Mempengaruhi Kinerja Profitabilitas Bank Perkreditan Rakyat Konvensional Di Provinsi Riau Dengan Efisiensi Sebagai Faktor Pemoderasi. Jurnal Tepak Manajemen Bisnis. 2016; VIII(2): 310-321. Jurnal Tepak Manajemen Bisnis 2016;8:310-21.

[5] Sakat ARenaldy. Analisis Faktor Internal Yang Memengaruhi Kinerja Keuangan Bank Perkreditan Rakyat Konvensional Di Provinsi Kalimantan Barat. Jurnal Manajemen Update 2021;10. 
[6] Sofyan M. Faktor-Faktor Yang Mempengaruhi Profitabilitas Bank Perkreditan Rakyat (BPR) di Provinsi Jawa Timur. Jurnal Inspirasi Bisnis Dan Manajemen 2019;3:63. https://doi.org/10.33603/jibm.v3i1.2093.

[7] Luh Anik Sri Agustini S, Gusti Ayu Nyoman Budiasih I. Analisis Faktor-Faktor Yang Memengaruhi Profitabilitas Bank Perkreditan Rakyat Di Kabupaten Badung. E-Jurnal Akuntansi Universitas Udayana 2014;8:609-19.

[8] Wardani, Made K, Ni LAPN. . Optimalisasi Profitabilitas Perbankan Melalui Pengelolaan Kecukupan Modal Dan Likuiditas Serta Risiko Kredit. Jurnal KRISNA: Kumpulan Riset Akuntansi 2021;12:320-7.

[9] Cahyono G. JMK (Jurnal Manajemen dan Kewirausahaan) Pengaruh Tingkat Kecukupan Modal (CAR), LDR, dan BOPO terhadap Profitabilitas. ManajemenKewirausahaan JMK 2018;3:13-24.

https://doi.org/10.32503/jmk.v3i1.332.

[10] Pandoyo. Faktor-Faktor Yang Mempengaruhi Profitabilitas Bank BPR Di Provinsi Jawa Barat. Jurnal Riset Manajemen Dan Bisnis (JRMB) Fakultas Ekonomi UNIAT 2019:127-36.

[11] Yeni A. Profitabilitas Bank Perkreditan Rakyat Di Kota Padang Di Tinjau Dari Rasio Likuiditas. Jurnal Benefita 2017;2:22 https://doi.org/10.22216/jbe.v2i1.2104.

[12] Anggreani K. Analisis Faktor-Faktor Yang Mempengaruhi Profitabilitas Bpr Di Kabupaten Tegal Periode 2016-2020 SKRIPSI Oleh. 2021.

[13] Ningrum RA, Hidayatulloh A. Determinan Kepatuhan Wajib Pajak Kendaraan Bermotor Di Kota Semarang. Krisna: Kumpulan Riset Akuntansi 2020;11:190-6. https://doi.org/10.22225/kr.11.2.1154.190-196.

[14] Roza Gustika. Analisa Pengaruh Bopo Terhadap Profitabilitas Pt. Bpr Swadaya Anak Nagari Simpang Empat. Jurnal Apresiasi Ekonomi 2015;3:157-66.

[15] Maryadi S, Basuki AT. Determinan Kinerja Keuangan Bank Perkreditan Rakyat Konvensional. vol. 15. 2014.

[16] Sari RRNRDTunjung. Analisis Pengaruh CAR, NPL, LDR Dan BOPO Terhadap Rentabilitas
Bank Perkreditan Rakyat Di Kabupaten Magelang. 2019.

[17] Wardhani PS and I, Poernaningrum S, Ismunawan. Impact Pandemi Covid-19 Terhadap Rentabilitas Bank Perkreditan Rakyat Konvensional Di Kabupaten Sukoharjo. Jurnal Bisnis Dan Akuntansi 2021;23:165-78.

[18] Aziri RD, Kamaliah, Savitri E. ANALISIS Faktor Yang Mempengaruhi Profitabilitas Pada Bank Perkreditan Rakyat Di Kota Pekanbaru (Periode Tahun 2012 Sampai Dengan Tahun 2016). Jurnal Tepak Manajemen Bisnis 2018;10:312-29.

[19] Hanifa R, Trianto A, Hendrich M. Determinan Profitabilitas Bank Perkreditan Rakyat di Kota Palembang Periode 20132018. Peringkat Akreditasi Sinta 2019; $18: 73$.

[20] Putu N, Pertiwi J, Made I, Suardikha S. Faktor-Faktor Yang Memengaruhi Profitabilitas Bank Perkreditan Rakyat. vol. 12. 2015.

[21] Juntoro S. Faktor Mempengaruhi Profitabilitas Bank PerkreditanRakyat. Jurnal Kajian Ilmiah Universitas Bhayangkara Jakarta Raya 2019;19:21321.

[22] Yuliati NN, Nengah Arsana I, Suardana IM. Risiko Usaha dan Rentabilitas pada BPR Konvensional di Nusa Tenggara Barat. vol. 18. 2021 .

[23] Istiqomah Azizah, Gregorius N. Masdjojo. Pengaruh Kredit Bermasalah, Porsi Kredit, Tingkat Efisiensi, Dan Kemampuan Modalterhadap Profirabilitas Pada Bank Perkreditan Rakyat Di Sumatera Barat Periode 2013-2016. Sendi, 2018, P. 74452. 